\title{
Institutional Capacity as Prevention of Abuse of Power of National Standard Policies for Private Universities in Jakarta
}

\author{
Mochammad Rozikin ${ }^{1}$, Mohamad Sofyan², Bambang Slamet Riyadi ${ }^{3, *}$ and Bambang \\ Supriyono ${ }^{4}$
}

\begin{abstract}
${ }^{1}$ Universitas Brawijaya, Deputy Dean III of the Faculty of Administration, Universitas Brawijaya, Malang, East Java, Indonesia; '2Universitas Brawijaya, Doctoral Program Student of Public Policy for Faculty of Administration, Universitas Brawijaya, Malang, East Java, Indonesia; ${ }^{3}$ Universitas Nasional, Faculty of Law, Jakarta, Indonesia; ${ }^{4}$ Professor, Universitas Brawijaya, Dean of the Faculty of Administrative Sciences, Malang City, East Java, Indonesia
\end{abstract}

\begin{abstract}
Research on this journal ontology that many private higher education institutions in Jakarta cover the impact of the policies of the Ministry of Research, Technology and Higher Education of the Republic of Indonesia as public officials to make and issue regulations that are very burdensome for the management of private higher education institutions. The purpose of this research is to criticize for improvement to the government of the Republic of Indonesia. This research used a qualitative method, while the research object was private universities in Jakarta that lack resources. The research subjects were resource persons who were aware of the constraints of the bankruptcy of private universities in Jakarta. The results of the study show that it has been proven that the state, in this case, the Ministry of Research, Technology and Higher Education of the Republic of Indonesia, makes and issues regulations that are very detrimental to the management of private higher education which is minimal in resources. The suggestion from this research shows that the government, by the constitution of the Republic of Indonesia, must be able to provide resource assistance efforts for private universities that are deficient.
\end{abstract}

Keywords: Institutional capacity, prevention, abuse of power, national standard policies, private universities.

\section{INTRODUCTION}

This study aims to analyze institutional capacity as a prevention of abuse of power of the National Standard for Private Higher Education in Jakarta as a higher education institution in Indonesia, acting as servants, designers and policy implementers and administrators (UNDP, 2011). In this case, there were several regulatory changes regarding the National Higher Education Standards in Indonesia which were made and published by the Government CQ. The Ministry of Research, Technology, and Higher Education has resulted in many private universities in Jakarta closing or going bankrupt.

The institutional capacity of private tertiary institutions in Indonesia as an educational management activity implies a plan to develop education, arts, and science to achieve the goal of educating the Indonesian nation. However, with all regulations from the government and the legislature as the holders of power and authority, using the abuse of power to make the National Higher Education Standards result in the capacity of institutions being burdened from the competition in the education business.

*Address correspondence to this author at the Universitas Brawijaya, Faculty of Administrative Sciences, Jalan MT, Haryono No. 163, Ketawanggede, Kec. Lowokwaru, Malang City, East Java 65145, Indonesia; Tel: +62341-553737; E-mail: mohammad.rozikin2020@gmail.com

Universitas Nasional, Jakarta, Indonesia;

E-mail: bambang.riyadi@civitas.unas.ac.id
Abuse of power or incapacity, both of which are the main parameters of whether or not there are deviations in the use of government authority, apart from other administrative law principles. If there is an element of abuse of power and arbitrariness, then there is an element of maladministration, and of course, there is an element of an act against the law, and the act becomes the personal responsibility of the official who commits it. Abuse of power is broader than unreasonable, but in the study of administrative law, both are needed to determine whether there is corruption, collusion, and nepotism by public officials. (Riyadi, et al., 2020, Vol 9, page 1294).

The capacity of private higher education institutions in Indonesia, as a prevention of abuse of power in implementing the National Standard of Higher Education policies, the uniqueness of institutional standards that can be used as a reference for the $\mathrm{Tr}$ Dharma of Higher Education is: balanced; harmonious and integrated with the framework of enrichment; quality improvement; independence and competitiveness (Mattjik, 2018). Understanding of institutional capacity is to prevent abuse of power. However, the government and the legislature that use their power often change the regulations of National Standards. The use (and abuse) of power in Indonesia cannot be understood based on the experience of other cultures, but it must be based on the experience of the Indonesian people themselves (Riyadi, et al. 2020, vol. 9, page 279) 
The power and authority of private tertiary institutions as executors of the National Standard of Higher Education policies require discretion, specificity, and uniqueness of institutional standards that are capable of being a reference for the Tri Dharma of Higher Education of: balanced; harmonious, and integrated with the framework of enrichment; quality improvement; independence and competitiveness (Mattjik, 2018). The use (and abuse) of power in Indonesia could not be understood based on the experience of other cultures, but it should be based on the Indonesian people themselves (Riyadi, 2020, vol 9, page 1293-1294)

Discretionary institutional capacity is deemed insufficient to meet the provisions for implementing the National Higher Education Standards policy, such as several concepts conveyed by scholars (Grindle \& Hilberbrand, 1995), (Grindle, 1997), (Brown, LaFond, \& Macintyre, 2001), (Matachi, 2006), (Purwaka, 2008) and others. This is due to differences in conditions, as well as factual demands that affect the conceptual development of institutional capacity, especially the readiness of the capacity of private universities in Indonesia, in compliance and policy exceedances. This also relates to the effectiveness, efficiency, and sustainability of the institution. Until now, the issue of discretion has become a public debate, especially among practitioners. These problems illustrate the readiness of policies in the capacity of private higher education institutions at 3 (three) different classification levels, that are Private Universities to exercise discretion of power as a prevention of conflicts of interest in higher education business competition; 1) fulfill with adjustments; 2) adequate, but necessary developed; and 3) unable to fulfill, need guidance, assistance, and facilities. The discretion of private universities is now faced with capacity demands which are: balance, harmony, independence, quality assurance, systematic and sustainable integration of the institution (Mattjik, 2018). The meaning of capacity, both tangible and intangible (Brown, LaFond, \& Macintyre, 2001: 4); (Langaas, Odeck, \& Bjørvig, 2007) \& (Antonova, 2011) is a characteristic of institutional capacity in implementing the National Higher Education Standards policy which is very burdensome from the continuation of private higher education efforts in Indonesia.

The problem of institutional capacity as a prevention of abuse of power in implementing the National Higher Education Standards, first, demands quality resources (lecturers, students, campus facilities, quality of graduation) by higher education quality assurance based on Law of the Republic of Indonesia Number No. 20 of 2003 concerning the National Education System. In 2015, Government Regulation Number 19 of 2005 concerning National Education Standards was issued. In 2013, Government Regulation of the Republic of Indonesia Number 32 of 2013 concerning Amendments to Government Regulations Number 19 of 2005 on National Standards Education was issued. Then, it changed back to Government Regulation of the Republic of Indonesia Number 13 of 2015 concerning National Education Standards, as well as policies of the Ministry of Research and Technology of the Republic of Indonesia and Higher Education Number 44 of 2015 concerning National Standards for Higher Education. In the shift and change in regulations, it shows that the government does not have a long-term structured National Education model. It gives the tendency of politicizing education to abuse of power and authority in the regulatory changes.

The second problem is that there is often a shift in the regulation of the National Higher Education Standards with the implication that private education institutions in Indonesia are going out of business or closed because they are required to experience the unequal quality of existing resources between corporations and universities; inequality of institutions and inequality between the quality of tertiary institutions that have large operational funds or management of higher education supported from abroad (Subkhan, 2010). The third problem, the institutional capacity of private universities as losers of the National Higher Education Standards made and published by the government and the legislature tends to not pay attention to the financial capacity of private tertiary education institutions (Aditya, 2014).

Based on the three problems mentioned above, it makes the researchers interested in conducting research and making the research results to be published in the International Journal of Criminology and Sociology. The reason for the researchers published in this journal is that the issue raised by the researchers is the behavior of higher education National Standard policymakers, not prioritizing the managers of private universities, causing injustice and disadvantage, in this case, it is by the scope of the IJCS.

\section{RESEARCH METHODS}

This study used a qualitative approach (Creswell, 2007) \& (McNabb, 2015) as the research method. The 
researchers understand that this study is faced with the possibility of subjectivity and the possibility of being trapped by bias that is the value requirement. Interpretation and construction of institutional capacity as a prevention of abuse of power of the national standard policy of private universities, especially in Jakarta, from various sources, are discussed.

The researchers obtained primary research data through informants who understand that institutional capacity is needed to prevent abuse of the National Higher Education Standards policy as the research subjects. In this case, the researcher poses structural questions to the informants as the resource persons. The research data were taken from books, scientific journals, and scientific articles. While for the tertiary research data, the researchers obtained it from various clues such as dictionaries and such to produce valid data in this study. Furthermore, the researcher analyzed the research data, expressed opinions of the research results, conclusions, and novelty suggestions from this study.

\section{THEORETICAL STUDY}

\subsection{Institutional Capacity}

Institutional capacity has the fundamentals of implementing the prevention of institutional authority. This is in line with Grindle's opinion which explains capacity as "the ability to carry out malpractice prevention as an institutional capacity" (Grindle M. S., 2002 \& 2007); (Brown, LaFond, \& Macintyre, 2001); (Knopfel, Larrue, Varone, \& Hill, 2007); (Purwaka, 2008) that is quite commonly applied. Capacity is also defined as "conditions according to norms" (Grindle M. S., 2000), as well as an intermediary and safeguarding what resources are owned (Dessing M., 1990) \& (Mahembe, 2011, pp. $12 \&$ 32); where these resources include social capital, financial capital and intellectual capacity capital (Atkinson \& Willis, 2006, p. 1) \& (Andersson \& Ledogar, 2008). This ability refers to the various functions and objectives of an institution (Fukuyama, 2004). Institutional capacity must be mobilized so that it is not static or productive in carrying out operations as it should be (Grindle, Mason, \& Rockefeller, 2010), mobilizing, balancing, and building/ realizing innovation (Grindle MS, 2002), even the ability to solve problems (Grindle MS, 2007). By institutional institutions, preventing the prevention of policy authority of the National Standard for Private Higher Education has an internal coherence value in the selection of actions taken by time, conditions, ongoing support, institutional structures capable of taking effective tasks, learning, and experience.

The study of the institutional capacity theory above is weakened by the power, in this case, the central government CQ. The Ministry of Research, Technology, and Higher Education, as the holder of power, makes and publishes National Education Standards which impact marginalized private higher education managers and even experience difficulties in operational costs.

Robert Klitgaard said that a power that tends to abuse power could harm people or institutions. Actors when they have power or monopoly, have unlimited discretion of authority and lack of accountability and responsibility are weak and independent control is weak. In this case, the government as the holder of power tends to abuse power by committing corruption $=$ monopoly plus discretionary policies, minus accountability. This condition is almost like what is happening in this country now (Riyadi, 2020;9; page 251).

According to Gois, white-collar crime, in this case, the government, involves the abuse of power by people who are in high positions where they have the opportunity to marginalize private education institutions that experience difficulties with the National Higher Education Standards for the Institute. White-collar crimes do not refer to social positions or offenders, but rather in the context in which white-collar crimes perpetrate and publish National Standards that do not do justice to marginalized institutions. White-collar crimes are violations of the norms of justice by implementing regulations that harm individuals or institutions. In this case, the government as the ruler commits a white-collar crime with abuse of power and authority. It is significantly detrimental to the legal, economic, or political-institutional arrangements for this purpose (Riyadi, Mustofa, 2020, 9, 28).

The terminology of institutional capacity as an entity can be influential and influenced. Some experts suggest that there is a broader context than simply dividing the viewpoint of the meaning of capacity into institutional structure or function. Capacity has to be linked with ownership and the possibility of creating capabilities that can almost link the impossibility into the one thing that might come true. This possibility was confirmed by M.S. Grindle, in the phrase, "... institutional balances of power in favor of change" (Grindle, 2002) which is more substantive than 
"institutional change" in the same writing, or also known as "stages of readiness" (Brown, LaFond, \& Macintyre, 2001). This needs a deeper understanding.

Like some of the problems in this study, Frissell, Liss, Warren, \& Hurley (1986) and Ebersole, Liss, \& Frissell (1997) and Cairns, Harris, \& Young (2005) explain that capacity is an initial potential or initial resource can 'allow'. Other researchers see it as a supporter in the problem development process, or a supporter that is parallel (Merino \& Carmenado, 2012) \& (Labonte \& Laverack, 2001), or the rationality of utilization for sustainability, simulations to minimize risk, prevention, resource innovation, or as feedback for the carrying the capacity itself (Jia, Cai, Chen, \& Zeng, 2018).

Another view of institutional capacity is the prevention of abuse of policy authority as the ability to be able to accommodate (absorptive), to recognize the value of new information, external information, assimilate it, and apply it to beneficial goals (Cohen \& Levinthal, 1990) \& (Volberda, Foss, \& Lyles, 2009), absorb and learn from other organizations (Lane \& Lubatkin, 1998), even have a dynamic nature in creating knowledge, utilizing it in increasing organizational capabilities and maintaining competitive advantage (Zahra \& George, 2002). The active nature of these capacities such as potential, carrying capacity, and carrying capacity is shown by Purwaka (2008: 5-8) in a separate structure.

Institutional capacity is a reliable asset in a variety of cultures and circumstances regarding the prevention of abuse of discretionary power that is too broad (Andersson \& Ledogar, 2008) \& (Atkinson \& Willis, 2006). The reliability characteristic of each capacity is considered a determinant to improve and is even considered as an initial trigger for risky decision making and utilizing the potential of the available resources (Harvie, 2004) which is not much different from the explanation of Brown, LaFond, \& Macintyre (2001), Grindle MS (2002), Grindle, Mason, \& Rockefeller (2010).

The point of view of institutional capacity as a prevention of abuse of power for national standard policies is the overall understanding of the meaning that each level of an entity, actions in the system affect various objectives, even the form and influence of behavior on institutional work (Milen, 2001, p. 7). It also relates to adaptability and ways of responding to risk (Smit \& Wandel, 2006). This ability can recognize the value of new information, assimilate it, and apply it for beneficial purposes (Volberda, Foss, \& Lyles, 2009), which is understood to be productive (Grindle, Mason, \& Rockefeller, 2010).

The explanation of institutional capacity above is deemed sufficient to represent and provide an understanding of the meaning of institutional capacity readiness as a prevention of abuse of power on national higher education standards policies. However, the interdependence between institutional capacities is an important concern. This understanding delivers theoretical concepts to the construction of institutional capacities that have dynamic or active characteristics and characteristics, although almost nothing gives an implicit meaning to the balance and dynamic relationship of each institutional capacity. Reviewing the literature may mean a priori, that for dynamic linkages in institutional capacities that seem to be put separately and seemingly do not influence each other.

\subsection{Components of Institutional Capacity}

Various perspectives on institutional capacity are put forward as an ideal concept construction in preventing the abuse of discretionary authority in the national standard policies of higher education. However, the "suitability" of each component seems to impose sanctions when the theoretical concept is placed on a different environmental phenomenon. Jean-Claude Thoenig gave a choice of position for institutional phenomena on different angles, even though this would attract mapping of capacity components down to the micro/local level (Thoenig, 2011). Mapping and institutional capacity structures that exist as phenomena are formed by components, therefore an institution exists, has a shape and function (Purwaka, 2008, p. 5).

At least this makes sense, although the varying characteristics make it a challenge (Peters, 2000), even in an unfavorable/ overall bad environment (Grindle, 1997). This is believed to require caution, even if it is met with similar experiences. Institutions are believed to be the birthplace of capacity components, at least from the starting point of their existence, until the institutions function dynamically. This explanation is interpreted as a transformation of institutional design to respond to uncertainty from various directions. The institution becomes instrumental rationality (Thoenig, 2011), especially in terms of coherence and its potential uses (Peters, 2000). 
Understanding the components of institutional capacity as a prevention of abuse of power in the policy of national higher education standards has important value for performing institutions. This component is summarized from various sources and the opinions of the scholars Kaplan (2001) emphasize the understanding of the capacity to be called competent. Some also sort the institutional capacity components into several static forms which are converted so that they can move dynamically (Purwaka, 2008, pp. 5-8). Brown, LaFond, \& Macintyre (2001) break down tangible and intangible components at several levels, such as UNDP (Imbaruddin, 2003). Meanwhile, Grindle (1997) divides the capacity strata into 5 interconnected dimensions to produce the desired institutional performance. These dimensions also relate to the description of the capacity component presented by Knopfel Larrue, Varone, \& Hill (2007, p. 255) in the scope of public policy institutions.

\section{ANALYSIS OF RESEARCH RESULTS AND DISCUSSION}

\subsection{Analysis of Research Results}

The researchers observed the field, identified what capacities exist in a private university, collected document data, and observed to understand the factual capacity of this institution. The in-depth observation was carried out by meeting with various sources to confirm the truth and grasping the implied meaning in policy implementation and institutional capacity readiness for implementing the National Higher Education Standards owned by private universities.

\subsection{Readiness of Private Higher Education Capacity}

The researcher started by collecting data on the implementation of the National Higher Education Standards policy in the first year, which was then reprocessed and interpreted. At the national level, the profile of higher education accreditation resulted from 8 criteria for the National Higher Education Standards as many as 993 accredited institutions, and 3,434 institutions not yet accredited (Ministry of Research, Technology and Higher Education of the Republic of Indonesia. 2016). The results of this accreditation illustrate the readiness of higher education capacity which is required to implement 24 higher education standards. The large number of institutions that have not been accredited is caused by many factors, especially the readiness of the capacity to apply 8 standards, instead of being able to apply 24 higher education standards.

Not only institutional accreditation, but higher education capacity readiness is also assessed at the Study Program level. The results are not much different. There are 18,903 accredited study programs, and 6,022 not yet accredited (Ministry of Research, Technology and Higher Education of the Republic of Indonesia. 2016). The results of the national university study program accreditation assessment also illustrate the readiness of the institutional capacity which is concerning.

The assessment and ranking of the Higher Education Accreditation Board show that in 2017-2018, the data of 2,243 tertiary institutions were accredited (National Accreditation Board for Higher Education 2019). It can be seen that there is a significant increase in the number of accredited tertiary institutions in the last two years. This accreditation is divided into several levels of assessment, that is the accredited A university reaches 95, 881 tertiary institutions accredited $B$, and 1,267 higher education accredited $C$ (National Accreditation Board for Higher Education 2019).

Analysis of the results of field data and data tracing is narrowed into private universities. The data describes the profile of private universities in Indonesia showing that there are 39 institutions accredited $A$ of private universities, 683 institutions of B accreditation, and 930 institutions of $C$ accreditation (National Accreditation Board for Higher Education, 2019). This number is higher than the number of state universities, considering a large number of private universities in Indonesia.

The researcher then narrowed the focus of the data into the scope of a smaller administrative area, that is private universities in the Province of the Special Capital Region of Jakarta. In Jakarta, there were 332 private universities in 2016. This number has shrunk to 316 private universities (based on Letter Number: $382 / \mathrm{L} 3 / \mathrm{KL} / 2019$ dated 31 July 2019). In this case, it is due to private tertiary institutions that are unable to organize and meet the provisions of the Higher Education National Standard policies due to competition for the quality of resources, so that some merge and even closed. The accreditation status of 316 Private Universities in the Special Capital City Region of Jakarta is, rank $A$ is 12 Private Universities, Rank B is 52 Private Universities, Rank $C$ is 47 Private Universities and minimum accreditation is 205 Private 
Universities (Based on Letter Number: 382 / L3 / KL / 2019 dated 31 July 2019).

The profile of the Private Higher Education Study Program in the Special Capital Region of Jakarta, according to the results of the accreditation, is still not maximal, as shown in the ranking as follows: $245(\mathrm{~A})$; 815 (B); 416 (C); 235 (C / minimum) and 17 have not been accredited (LL DIKTI III, 2018). The overall data above illustrates the readiness of the capacity of private tertiary institutions, at 3 (three) levels of readiness: 1) capacity to meet with adjustments, 2) capacity is sufficient but needs to be developed and 3 ) capacity is not able to meet; it needs guidance and facility assistance.

\subsection{Private Higher Education Institutional Capacity}

The institutional capacity of higher education as long as the researchers' understanding has many different components, at least from some of the theoretical frameworks constructed previously. Researchers met various levels of resource persons and practitioners of higher education to explore the meaning and truth of the institutional capacity framework of private universities. Researchers also explored various perspectives from the Head of Institutions, Deputy Leaders, and Staff to the lowest level of private higher education institutions.

The analysis of the results of interviews with research subjects regarding institutional capacity as a prevention of abuse of power and authority in the higher education national standard policy resulted in various perspectives with different characteristics. Although in the end, the researcher analyzes the preventive policy constructs of interconnected components and moves dynamically. The results of an interview with one of the Vice Chancellors for Academic Affairs at a Private Higher Education in Jakarta made a statement;

"That the Institutional Capacity as a prevention of abuse of power in the implementation of the National Higher Education Standard Policy is very effective, but only private universities have sufficient resources. If the private higher education institution is lacking in resources, the Institute will close or go bankrupt. In this case the government CQ. The Ministry of Research, Technology and Higher Education of the Republic of
Indonesia, making regulations reflect injustice to less well-off private universities, should assist so that university institutions that are less well off with resources can run businesses to participate in the development of the Indonesian nation's intelligence."

Based on the analysis of the research subject from the sources above shows, it can be stated that the state through the Ministry of Research, Technology and Higher Education, as the power to foster all universities in Indonesia is very burdensome to private universities that lack resources by issuing National Standard regulations.

The results of the research subject as the next resource were from one of the Vice-Chancellors I of Private Universities in the Special Capital Region of Jakarta. In addition to the regulations issued by public officials, in this case, the Ministry of Research, Technology and Higher Education of the Republic of Indonesia, actions were taken by the institutional capacity to prevent abuse of power in implementing the National Higher Education Standards policy, are also influenced by the abuse of power system that has been formed in state institutions and social and cultural aspects around,

In my opinion, the Institutional Capacity as a prevention of abuse of power in implementing the policy of national higher education standards is very good, but the government, in this case, is the Ministry of Research, Technology and Higher Education, should be able to provide guidance and direction to private higher education institutions that lack various resources, not having to manage with private higher education institutions that have been able to come from various sources. This can be said by the government as the holder of power in national education tends towards abuse of power, so that it is detrimental to private universities that lack marginalized resources.

According to the analysis of the research subject from the above sources, it can be stated that the existence of the regulation of the National Higher Education Standards is very burdensome to the management of private universities in Jakarta. Only 
private universities with strong resources can perform it, while private universities that are lacking resources will go bankrupt and even be ordered to go bankrupt. This will harm the teaching staff who have been teaching for a long time and even lose their livelihoods.

The research subject who stated that the regulation of National Higher Education Standards was very burdensome for the management of private universities that were less well off in resources is delivered by one of the internal officials of the Private Higher Education Foundation in Jakarta who said that,

Even though the existence of Institutional Capacities as a prevention of abuse of power in the National Higher Education Standards policy is very good for private universities that are capable and have sufficient resources, but for private universities that lack resources, they will go bankrupt and even close. The government as a power in the development of higher education has committed an abuse of power to reflect the siding with financial power. And it can be stated that state administrators of education affairs do not have justice for education managers who lack resources.

From the analysis of the research subject from the sources above, it can be stated that the regulation of the National Higher Education Standards has made the management of many private universities in Jakarta go bankrupt and even closed.

The subject of the next research on the influence of the environment and institutional action in the context of Institutional Capacity as the prevention of abuse of power in the Higher Education National Standard policy was confirmed by one of the Chancellors of Private Higher Education in Jakarta. The Chancellor stated,

In an environment of institutional capacity as prevention of abuse of power in higher education policies, our view includes 4 substance pillars, namely 1) technological development, optimization of human resource capacity 3) scientific development, 4) orientation of lecturers as educators, facilitators, mentors, and counselors. 5) students who have the ability: theoretical, practical, good moral and spiritual".
Based on the analysis of the statement of the research subject from the sources above, it can be stated that the regulation of the National Higher Education Standards makes the management of private universities in Jakarta required to procure all resources, but there is no assistance from the government as a state that should provide all resources assistance to private universities with lack of resources.

The subject of further research, one of the Vice Chancellors for the Academic Affairs of Private Higher Education in Jakarta, on the influence of institutional capacity as a prevention of abuse of the power of higher education national standard policies in the external environment stated that it does not only arise from the successful practice of organizational managerial concepts in shaping organizational culture.

"Whereas with the required National
Higher Education Standards during
several leadership changes, private
universities can only survive by being able
to adapt to various regulations and
policies, both macro and micro, which
eventually go bankrupt and closed. In this
case, the government does not reflect as a
country that protects from efforts to
educate the nation, only for private higher
education entrepreneurs who are strong
with a capital of various resources.

Based on the analysis of the statement of the research subject above, it can be stated that the influence of the external environment also arises from the understanding of government authorities to carry out regulations that are incompatible with the management of private universities who are less capable of resources in the scope of the national, regional and international environment. Also, other higher education institutions, as well as the business sector, also influence the actions taken by the institutions to go out of business or go bankrupt.

\section{DISCUSSION}

Based on the results of the research and analysis above, it can be found a synthesis of the components of the Institutional Capacity of Private Higher Education as the Prevention of Abuse of Power in the National Higher Education Standard Policy that must be implemented by the government, that the environment of action, the context of relations between sectors, the internal task network, the organization, human 
resources, facilities and infrastructure, information technology, finance, and social capital. This capacity can at least fulfill as well as becomes a construction of the concept of exceeding standards in the National Higher Education Standards policy as a way to generate competitive advantage, as well as an adaptation to strategy. This is a new perspective that explains the readiness of the institutional capacity of private universities. In this case, it is very burdensome for the management of private tertiary institutions that lack resources, so that they experience mergers and even go bankrupt and closed.

Capacity readiness initiated by Brown, LaFond, \& Moacintyre (2001) and institutional capacity by Grindle \& Hilberbrand (1995), \& M.S. Grindle (1997) is the beginning of the conceptual construction idea of the institutional capacity of private universities to participate in preventing abuse of power in the National Standard policy in uncertain conditions, or the institution is in an unfavorable environment (overall is bad) (Grindle, 1997) \& (Peters, 2000). This a priori idea gets a light when the facts give rise to meaning that makes sense. Although the results of the accreditation of private universities explain that the level of readiness of the institution to implement the National Higher Education Standard policy is divided into three levels;

1. Institutional capacity to prevent abuse of power.

2. The capacity of the institution is ready to implement regulatory policies from the government, and

3. The capacity for not being able to meet the implementation of the National Higher Education Standard regulations is very burdensome for the operational burden of private tertiary institutions that are short of resources, so it needs guidance and assistance from the state facilities.

The first level, the adequacy, and reliability of the institutional capacity of the integrity prevention of abuse of power, the institution only needs to adjust its performance with the National Higher Education Standard Policy framework. At the second level, institutions can still adapt quite easily by filling in the gaps in institutional capacity. Meanwhile, at the third level, institutions need to work hard to be able to adjust the capacity of the institution at least to be able to meet the standards in the National Higher Education Standards policies. In this case, if the management of private universities is lacking in resources, the government should be able to help with funding. If the government does not care about funding, private higher education institutions will go out of business and even go bankrupt.

The difference in the level of readiness of institutional capacity as a prevention of abuse of power in the National Higher Education Standards policy as shown by private higher education institutions explains different conditions and characteristics (Grindle, 2000). Each of these levels of readiness is related to a dynamic capacity component (Grindle, Mason, \& Rockefeller, 2010), mobilizing, balancing, and being able to build/ realize (Grindle, 2002), and even the ability to solve problems (Grindle, 2007). The value of the coherence of the institutional capacity components of private tertiary institutions is in the selection of institutional actions, their sustainability support for institutional performance, and effective institutional process mechanisms by forging experiences and continuous learning (Milen, 2001), (Smit \& Wandel, 2006), (Merino \& Carmenado, 2012) \& (Labonte \& Laverack, 2001), (Jia, Cai, Chen, \& Zeng, 2018). Adaptive mechanism and relationship between dynamic components and coherent values between institutional capacities further explain the context of conditions as well as the intentions described by Grindle (1997 \& 2002), Grindle \& Hilberbrand (1995) about "...institutional balances of power in favor of change". Likewise, the purpose of Brown, LaFond, \& Macintyre (2001) explanation on the readiness of institutions to move dynamically.

The dynamic nature of each component of institutional capacity can meet and even exceed the national higher education standard policies. Institutional capacity can prevent abuse of power by utilizing and empowering institutional capacities: 1) the environment for preventive measures, 2) relations between sectors must be relevant, 3) internal task networks run properly, 4) private higher education organizations run according to standard procedures, 5) human resources that support in preventing the use of authority, 6) facilities and infrastructure according to national standards, 7) information technology to support operations, 8) sufficient finance for higher education management, and 9) social capital. These components are institutional assets (Atkinson \& Willis, 2006), (Andersson \& Ledogar, 2008), \& (Purwaka, 2008) which have distinctive reliability characteristics to be able to initiate action, determine even risky decision making (Harvie, 2004), (Brown, LaFond, \& Macintyre, 2001), (Grindle, 2002), \& (Grindle, Mason, \& Rockefeller, 2010). 
The nine institutional capacities can move in parallel (Merino \& Carmenado, 2012) \& (Labonte \& Laverack, 2001), but can also move dynamically when the institutional capacity is converted (Purwaka, 2008). The dynamics of environmental conditions then lead to a transformation of institutional designs to answer uncertainty from all directions, so that the institution becomes a rational, instrumental vessel (Thoenig, 2011) \& (Peters, 2000). The context of the private tertiary education environment which includes two factors, namely the environment that influences it and the institutional action was taken by the institution is a clear picture. Environmental factors consist of regulations/legal contexts issued by the government, aspects of the surrounding social and cultural conditions, national and international strategic issues that form a rule of the game which then affects the private universities as higher education institutions. The institutional action of private universities also finds a dilemma in two choices in interpreting this environmental influence, that is by considering it as a threat/ challenge or potential opportunity for the institution.

Institutional Capacity as the Prevention of Abuse of Power in the National Standard Policy for Higher Education in Jakarta depends on the use and support of information technology in the institutional process to become one of the concentrations for several scholars (Grindle, 1989), (Grindle, 2001), (Grindle, Mason, \& Rockefeller, 2010), (Fountain, 2001), (Langaas, Odeck, \& Bjørvig, 2007), (Antonova, 2011), \& (Aswati, Mulyani, Siagian, \& Syah, 2015). The development and utilization of current technology greatly affect the implementation of higher education. The internal guidance system for Private Higher Education must be integrated and connected using a cloud technology base (online file) with a government information management system known as the Government's Higher Education Database. Whereas internally, this information technology system is referred to as the Higher Education Database which has different terms in each of the Operational Private Universities, this system requires separate personnel expertise. This system is also a supporting medium for the implementation of higher education, especially in the operation of academic and non-academic activities in connection with the use and allocation of facilities and infrastructure, finance, monitoring, and evaluation of the performance of human resources (lecturers, staff, and students), as well as a management center of Private Higher Education official email data as a whole.
Apart from the use of information technology to support the operation of higher education operations, private universities also depend on financial capacity. The availability and adequacy of this capacity have an impact on the sustainability of the institution. Grindle \& Hilberbrand (1995) \& Grindle (1997) put it as part of an organization and focus on its management context. Brown, LaFond, \& Moacintyre (2001) also put it at the organizational level, and Kaplan (2001) called it material resources as material needed in the institutional process. These ideas are correct, therefore, this capacity is managed and connected integrally with the civil service of private universities. The financial management system of private universities must also be audited regularly to determine the level of reliability of their ability to support the overall operation of higher education. However, in the context of implementing higher education, private universities do not rely as much as possible on funding sources from tuition fees incurred by students. We strive to obtain financial sources for private universities by utilizing their internal capacities, such as business units, research grants or government funding allocations, or other legitimate sources. The dynamics of the institution and its impact, management, and evaluation of the financial capacity of private universities explain the dynamic nature of this component, especially for the adaptive action of the institution. The strategy of realizing independent financial resources and their governance requires human resources to think rationally, effectively, and efficiently. Therefore, the leadership capability in acting and the support of good personnel are the determinant factors of the institution's adaptability.

Institutional capacity as a prevention of abuse of power and authority in the policy of national standards for private tertiary institutions in Jakarta, independent institutions are needed to check and balance several regulations issued by the government to the detriment of the management of private tertiary education which lacks resources, even exceeding the standard policies of the National Education Standards. Height is social capital. Schiuma \& Lerro (2008), Andersson \& Ledogar (2008), \& Atkinson \& Willis (2006) implicitly emphasize social capital as a fundamental factor that can affect the environment. Other scholars do not explain it specifically, even though it is implicitly part of the action environment, as well as individual capabilities both personally and collectively (Grindle \& Hilberbrand, 1995) \& (Brown, LaFond, \& Moacintyre, 2001). In the 
higher education environment, social capital as a capacity becomes a unique phenomenon even though some private universities are less aware of this as an institutional capacity. The institutional social capital of private universities can come from the figure of the founder, the achievements of the institution, the achievements, and the good name of the lecturers and students. This capacity is a reflection of the readiness of institutions in providing higher education and supporting adaptive actions to deal with uncertain environmental conditions. The capabilities of leaders and internal institutional personnel, as well as competitive advantages over other capacities (iconic institutional names, social brand marks, characteristics of institutionalized socio-cultural identities, etc.) that accumulate to form the social capital of the institution, can, in turn, affect the institutional environment of higher education. Therefore, social capital as a capacity can become a reliable support for adaptive institutional action even in the worst environmental condition, as well as a distinctive character as an institution's readiness to meet or exceed the policy standards of the National Higher Education Standards.

\section{CONCLUSION}

Based on the results of the research and discussion above, the researchers draw the following conclusion. The purpose of this research is useful for the government, especially the Ministry of Research, Technology, and Higher Education as public officials to make quality regulations less burdensome for the implementation of private higher education.

The Institutional Capacity of Private Universities in Jakarta plays a role in preventing the abuse of power and authority from the government as the holder of the national standard policy for higher education so that it is very burdensome for the operational costs of managing private universities that lack various resources. In this case, the Ministry of Research, Technology and Higher Education of the Republic of Indonesia publishes National Higher Education Standards which are always inconsistent and always changing in issuing regulations, resulting in private universities required to merge and even go bankrupt, as a result of the state that provides no guidance and helps all resources.

The suggestion from this research is that it is hoped that the government, in this case, the Ministry of Research, Technology and Higher Education can assist private universities in Jakarta, which are experiencing a lack of resources as by the constitution of the Republic of Indonesia, that the state guarantees the intellectual development of its people.

\section{REFERENCE}

Aditya, M. (2014). Perhitungan Idle Capacity Dengan Menggunakan CAM - I Capacity Model Dalam Rangka Efisiensi Biaya Pada PT X. Esensi Jurnal Bisnis dan Manajemen, Vol. 4, No. 2, Agustus 2014, 140-155. https://doi.org/10.15408/ess.v4i2.1961

Andersson, N., \& Ledogar, R. J. (2008). The CIET Aboriginal Youth Resilience Studies: 14 Years of Capacity Building and Methods Development in Canada. CIHR IRSC Pimatisiwin; 6 (2), 65-88.

Antonova, S. (2011). "Capacity -building" in Global Internet Governance: The Long-term Outcomes of "Multistakeholderrism". Regulation \& Governance (2001) 5, 425-445. https://doi.org/10.1111/j.1748-5991.2011.01117.x

Aswati, S., Mulyani, N., Siagian, Y., \& Syah, A. Z. (2015). Peran Sistem Informasi dalam Perguruan Tinggi. Jurnal teknologi dan Sistem Informasi, Volume 1, Nomor 2, 79-86.

ATD, A. t. (2018). Institutional Capacity Framework and Assessment Tool. Portland \& Silver Spring: Achieving the Dream.

Atkinson, R., \& Willis, P. (2006). Community Capacity Building - A Practical Guide. Tasmania - Australia: Housing and Community Research Unit - School of Sociology and Social Work - University of Tasmania.

Brown, L., LaFond, A., \& Macintyre, K. (2001). Measuring Capacity Building. Chapel Hill: University of North California.

Cairns, B., Harris, M., \& Young, P. (2005). Building the Capacity of the Voluntary Nonprofit Sector: Challenges of Theory and Practice. Intl Journal of Public Administration, 28, 869-885. https://doi.org/10.1081/PAD-200067377

Cohen, W. M., \& Levinthal, D. A. (1990). Absorptive Capacity: A New Perspective on Learning and Innovation. Administrative Science Quarterly, Vol. 35, No. 1, Special Issue: Technology, Organizations, and Innovation. (Mar., 1990), 128-152. https://doi.org/10.2307/2393553

Creswell, J. W. (2007). Qualitative Inquiry and Research Design: Choosing Among Five Approaches. Thousand Oaks: Sage Publications, Inc.

Dessing, M. (1960). Support for Microenterprises: Lesson for SubSahara Africa. Sub-Sahara, Africa: Library of Congress Cataloging-in-Publication Data Harvard Institute for International Development at Harvard University.

Ebersole, J. L., Liss, W. J., \& Frissell, C. A. (1997). Restoration of Stream Habitats in the Western United States: Restoration as Reexpression of Habitat Capacity. Environmental Management Vol. 21, No. 1, 1-14. https://doi.org/10.1007/s002679900001

Fountain, J. E. (2001). Building the Virtual State: Information Technology and Institutional Change. Cambridge: Brookings Institution Press.

Frissell, C. A., Liss, W. J., Warren, C. E., \& Hurley, M. D. (1986). A Hierarchical Framework for Stream Habitat Classification: Viewing Streams in a Watershed Context. Environmental Management Vol. 10, No. 2, 199-214. https://doi.org/10.1007/BF01867358

Fukuyama, F. (2004). The Imperative State - Building. Journal of Democracy, 17-31. https://doi.org/10.1353/jod.2004.0026 
Grindle, M. S. (1989). The New Political Economy: Positive Economy and Negative Politics. World Bank Publication. https://doi.org/10.1016/S0305-750X(96)00123-4

Grindle, M. S.. (1997). Divergent Cultures? When Public Organizations Perform Well in Developing Countries. World Development, 481-495. https://doi.org/10.2139/ssrn.274151

Grindle, M. S. (2000). Designing Reforms: Problems, Solutions, and Politics. Cambridge: John F. Kennedy School of Government Harvard University. https://doi.org/10.2139/ssrn.284013

Grindle, M. S.. (2001). Despite the Odds:The Political Economy of Social Sector Reform in Latin America. Cambridge: Kennedy School of Government - Harvard University.

Grindle, M. S.. (2002). Interests, Institutions, and Reformers: The Politics of Education Decentralization in Mexico. Cambridge: Kennedy School of Government Harvard University.

Grindle, M. S.. (2007). Goog Enough Governance Revisited. Development Policy Review, 2007, 25 (5), 553-574. https://doi.org/10.1111/j.1467-7679.2007.00385.x

Grindle, M. S., \& Hilderbrand, M. E. (1995). Building sustainable capacity in the public sector: What can be done? Public Administration and Development, https://doi.org/10.1002/pad.4230150502

Grindle, M. S., Mason, E. S., \& Rockefeller, D. (2010). Social Policy in Development: Coherence and Cooperation in The Real World. Cambridge: Harvarde Kennedy School. https://doi.org/10.2139/ssrn.1624871

Harvie, C. (2004). East Asian SME Capacity Building, Competitiveness and Market Opportunities in a Global Economy. Faculty of Business - Economics Working Papers, 1-28.

Imbaruddin, A. (2003). Understanding Institutional Capacity of Local Government Agencies in Indonesia. Canberra: The Australian National University.

Jia, Z., Cai, Y., Chen, Y., \& Zeng, W. (2018). Regionalization of water environmental carrying capacity for supporting the sustainable water resources management and development in China. Resources, Conservation \& Recycling, 134, 282293.

https://doi.org/10.1016/j.resconrec.2018.03.030

Kaplan, A. (2001). Capacity Building: Shifting The Paradigms of Practice. In D. Eade, \& E. Legteringen, Debating Development NGOs and The Future (pp. 322-335). Tottemham Court Road, London: Oxfam GB for Oxfam International. https://doi.org/10.3362/9780855986858.022

Kaplan, R. S., \& Anderson, S. R. (2003). Time-Driven Activity-Based Costing. SSRN 485443, 1-18. https://doi.org/10.2139/ssrn.485443

Kemenristekdikti. (2016). Kebijakan Kemristekdikti dalam Mewujudkan PTS Bermutu Melalui Akreditasi Institusi. Jakarta: Kementerian Riset, Teknologi, dan Pendidikan Tinggi Republik Indonesia.

Khan, A. S. (2014). Education Role in Capacity Building. International Journal of Agricultural Extension, 05-11.

Knopfel, P., Larrue, C., Varone, F., \& Hill, M. (2007). Public Policy analysis. Bristol: First Published in Great Britain. https://doi.org/10.2307/j.ctt9qgz7q

Labonte, R., \& Laverack, G. (2001). Capacity building in health promotion, Part 1: For whom? And for what purpose? Critical Public Health, Vol. 11, No. 2, 111-117. https://doi.org/10.1080/09581590110039838

Langaas, M. D., Odeck, J., \& Bjorvig, K. (2007). The Concept $f$ Institutional Capacity Building and Review of Road Sector Projects. In 23rd Piarc World Road Congress Paris, 17-21 September 2007.
Lane, P. J., \& Lubatkin, M. (1998). Relative Absorptive Capacity and Interorganisational Learning. Strategic Management Journal, Vol. 19, 461-477.

https://doi.org/10.1002/(SICI)10970266(199805)19:5<461::AID-SMJ953>3.0.CO;2-L

Matachi, A. (2006). Capacity Builidng Framework: UNESCO - IICB. Addis Ababa, Uthopia: United Nations Economic Commission for Africa.

Mattjik, M. (2018, Februari 16). Repositori: Bangun Dari Tidur Panjang. Retrieved September 4, 2018, from spmi.ristekdikti.go.id: http://spmi.ristekdikti.go.id/repositori/ 5a79d6f4a54a05499d1fda74

McNabb, D. E. (2015). Research Methods For Political Science : Quantitative and Qualitative Approaches. Milton Park: Routledge - Taylor \& Francis Group. https://doi.org/10.4324/9781315701141

Merino, S. S., \& Carmenado, I. d. (2012). Capacity building in development projects. Procedia Social and Behavioral Sciences, 46, 960-967. https://doi.org/10.1016/j.sbspro.2012.05.231

Milen, A. (2001). What do we know about capacity building? An overview of existing knowledge and good practice. Geneva: Department of Health Service Provision-World Health Organization.

Peters, B. G. (2000). Institutional Theory: Problems and Prospects. Wien, Vienna: Institut für Höhere Studien (IHS), Institute for Advanced Studies.

Purwaka, T. H. (2008). Model Analisis Pengembangan Kapasitas Kelembagaan. Jakarta: Fakultas Hukum Unika Atma Jaya.

Schiuma, G., \& Lerro, A. (2008). Intellectual capital and company's performance improvement. Measuring Business Excellence. https://doi.org/10.1108/13683040810881153

Sendegeya, A.-M., \& Chiguvare, Z. (2016). The Role of Academia in Capacty Building for Sustainable Energy Development: The Case of Namibia. Enegery Procedia, 93, 218-222. https://doi.org/10.1016/j.egypro.2016.07.173

Smit, B., \& Wandel, J. (2006). Adaptation, adaptive capacity and vulnerability. Global Environmental Change, 16 , 282-292. https://doi.org/10.1016/j.gloenvcha.2006.03.008

Riyadi, Slamet Bambang, et al., (2020), Discretion of Power of the Indonesian National Police Impacts the Abuse of Power in the Case of Letter Forgery of Red Notice "Fugitive Djoko Tjandra" International Journal of Criminology and Sociology, 9, 1292-1300. https://doi.org/10.6000/1929-4409.2020.09.148

Riyadi, Slamet Bambang, and Mustofa, Muhammad (2020), Corruption Culture on Managing Natural Resources: The Case Political Crime "Papa asking Stock of PT. Freeport Indonesia" International Journal of Criminology and Sociology, 9, 26-36.

Riyadi, Slamet Bambang (2020) Culture of Abuse of Power Due to Conflict of Interest to Corruption for Too Long on The Management from Resources of Oil and Gas in Indonesia, International Journal of Criminology and Sociology, 9, 247254.

Riyadi, Slamet Bambang (2020), Culture of Abuse of Power in Indonesia from the Perspective of Criminology and Law, International Journal of Criminology and Sociology, 9, 274284

Subkhan, E. (2010). Mempertanyakan Orientasi World Class University. Seminar Nasional BEM FE UNSOED (pp. 1-21) Purwokerto: http://www.academia.edu.

Thoenig, J.-C. (2011). Institutional Theories and Public Institutions: New Agendas and Appropriateness. . In P. B. J.Pierre, The Handbook of Public Administration (pp. 185-101). London, United Kingdom: Sage Publications Ltd.

UNDP. (2011). Governance Principles, Institutional Capacity and Quality. New York: UNDP 10017 USA. 
Volberda, H.W, Foss, N.J, \& Lyles, M.A. (2009). Absorbing the Concept of Absorptive Capacity. Retrieved from http://hdl.handle.net/1765/76125

Zahra, S. A., \& George, G. (2002). Absorptive Capacity: A Review, Reconceptualization, and Extension. Academy of

DOI: https://doi.org/10.6000/1929-4409.2021.10.34

(C) 2021 Rozikin et al.; Licensee Lifescience Global.

This is an open access article licensed under the terms of the Creative Commons Attribution Non-Commercial License (http://creativecommons.org/licenses/by-nc/3.0/) which permits unrestricted, non-commercial use, distribution and reproduction in any medium, provided the work is properly cited.

Management Review, Volume 27, Issue 2. Research Collection Lee Kong Chian School Of Business, 185-203. https://doi.org/10.5465/amr.2002.6587995

Received on 07-12-2020

Accepted on 22-01-2021 21 